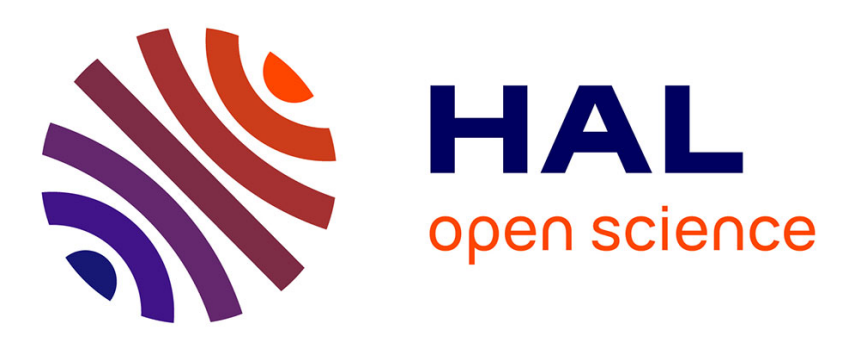

\title{
Effect of different dietary linseed sources on fatty acid composition in pig tissues
}

\author{
Auriane de Tonnac de Villeneuve, S. Karim-Luisset, Jacques Mourot
}

\section{To cite this version:}

Auriane de Tonnac de Villeneuve, S. Karim-Luisset, Jacques Mourot. Effect of different dietary linseed sources on fatty acid composition in pig tissues. Livestock Science, 2017, 203, pp.124-131. 10.1016/j.livsci.2017.03.022 . hal-01614432

\section{HAL Id: hal-01614432 \\ https://hal.science/hal-01614432}

Submitted on 10 Oct 2017

HAL is a multi-disciplinary open access archive for the deposit and dissemination of scientific research documents, whether they are published or not. The documents may come from teaching and research institutions in France or abroad, or from public or private research centers.
L'archive ouverte pluridisciplinaire HAL, est destinée au dépôt et à la diffusion de documents scientifiques de niveau recherche, publiés ou non, émanant des établissements d'enseignement et de recherche français ou étrangers, des laboratoires publics ou privés. 


\section{Author's Accepted Manuscript}

Effect of different dietary linseed sources on fatty acid composition in pig tissues

A De Tonnac, S Karim-Luisset, J Mourot

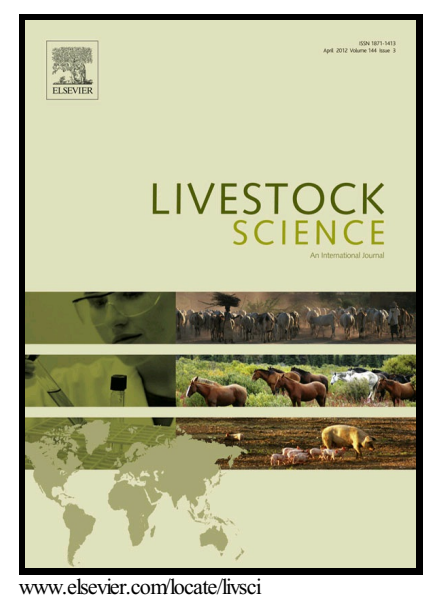

PII:

S1871-1413(17)30101-4

DOI: $\quad$ http://dx.doi.org/10.1016/j.livsci.2017.03.022

Reference: LIVSCI3190

To appear in: Livestock Science

Received date: 16 September 2016

Revised date: 25 March 2017

Accepted date: 27 March 2017

Cite this article as: A De Tonnac, S Karim-Luisset and J Mourot, Effect of different dietary linseed sources on fatty acid composition in pig tissues Livestock Science, http://dx.doi.org/10.1016/j.livsci.2017.03.022

This is a PDF file of an unedited manuscript that has been accepted fo publication. As a service to our customers we are providing this early version o the manuscript. The manuscript will undergo copyediting, typesetting, an review of the resulting galley proof before it is published in its final citable form Please note that during the production process errors may be discovered whic. could affect the content, and all legal disclaimers that apply to the journal pertain 


\section{Effect of different dietary linseed sources on fatty acid composition in pig tissues}

De Tonnac, $\mathrm{A}^{1,2}$, Karim-Luisset, $\mathrm{S}^{1}$, Mourot, $\mathrm{J}^{1, \dagger}$

${ }^{1}$ PEGASE, Agrocampus Ouest, INRA, 35590, Saint-Gilles, France

${ }^{2}$ Valorex, La Messayais, 35210 Combourtillé, France

${ }^{\dagger}$ Corresponding author: INRA UMR1348 Domaine de la Prise 35590 Saint-Gilles, France. Tel: +33 223485061, email address: jacques.mourot@inra.fr

Short title: Tissue location and diet effect on fatty acid composition of pigs tissues

Key words: tissue location; linseed; fatty acids; pig

\section{Abstract}

This study compared effects of diets containing regular or low fiber extruded linseed and of tissue location on deposition of fatty acids (FA) in pigs. Thirty-six crossbreed growingfinishing male pigs (51 kg initial liveweight) received one of three experimental diets: control, extruded linseed (EL) and low fiber extruded linseed (EL-). Diets respectively contained 0.57, 3.90 and $4.35 \mathrm{~g}$ of $\alpha$-linolenic acid (ALA) per $\mathrm{kg}$ of feed. Pigs were stunned at $115 \mathrm{~kg}$ liveweight and tissues were sampled to determine their FA composition (g/100g of total FA). Compared to EL diet, the EL- diet increased the ALA content by $18 \%$ in the longissimus dorsi muscle, $19 \%$ in the diaphragm, $9 \%$ in subcutaneous adipose tissues and $17 \%$ in flare fat. Content of n-3 polyunsaturated FA (PUFA) significantly increased with both linseed diets in the diaphragm, flare fat and subcutaneous adipose tissues in the back (SCB) and ham (SCH). The longissimus dorsi and semimembranosus muscles contained more PUFA and n-3 PUFA derivatives and less C18:3 n-3 than the diaphragm. Flare fat contained the largest percentage of SFA, followed by SCB and belly. In contrast, subcutaneous adipose tissue in the neck $(\mathrm{SCN})$, adipose tissue in the ham $(\mathrm{IH})$ and the $\mathrm{SCH}$ had a higher percentage of PUFA and C18:3 n-3 than belly, SCB and flare fat. The SCB contained the most C22:6 n-3, while the $\mathrm{SCH}$ contained the most C20:5 n-3. These results revealed the greater capacity of flare fat, SCB and to a lesser extent, the belly to synthesize saturated FA and the greater capacity of SCN, SCH and IH to store PUFA. This study confirmed the utility of feeding animals with interesting FA to increase their content in meat and by that to improve consumer's health.

\section{Introduction}

The European population does not consume enough n-3 polyunsaturated fatty acids (PUFA) compared to its consumption of n-6 PUFA (Anses, 2011). People consume an 


\section{ACCEPTED MANUSCRIPT}

average of 15 n-6 PUFA for every n-3 PUFA, whereas public health policies recommend consuming five n-6 PUFA for every n-3 PUFA. The n-3 PUFA are involved in many body functions such as vision or brain development and consuming too few of them can cause health problems such as cardiovascular disease and metabolic disorders. For this reason, consumers must rebalance their PUFA consumption ratio by consuming more n-3 PUFA, whose $2 \mathrm{~g}$ of $\alpha$-linolenic acid (ALA) per day (Anses, 2011).

Livestock could serve as a source of n-3 PUFA, because most of dietary fatty acids (FA) that they ingest are deposited in their tissues (Mourot and Hermier, 2001). For instance, the French "Bleu Blanc Coeur" path produces ALA rich animal products for human consumption from animals fed diet with linseed (Mourot and de Tonnac, 2015). However, the efficiency of FA deposition depends on multiple factors. First, it depends on the ingredients in the diet and the digestibility of the diet's fat. A previous experiment examined the digestibility of linseed that had been crushed or extruded with different technological methods (Noblet et al., 2008). Second, FA composition in an anatomical tissue depends on its location in the carcass (Kloareg et al., 2007; Monziols et al., 2007). In France, except for certain parts of the carcass, the entire pig is consumed as fresh meat $(30 \%)$ or is transformed $(70 \%)$ without changing its FA profile (Guillevic et al., 2009a). It is important to know whether certain tissues capture or synthesize healthier FA than others. We hypothesized that pigs receiving low-fiber extruded linseed diets will deposit more ALA in their tissues than those receiving extruded linseed diets because the former has higher digestibility. This study examined the FA composition of different muscles and adipose tissue in pigs fed a control diet or a diet containing regular or low-fiber extruded linseed.

\section{Materials and Methods}

Animals were reared and slaughtered at the INRA experimental site in Saint-Gilles, France, according to a protocol in accordance with French legislation and conducted under the responsibility of J. Mourot (approval number 04738; ministerial experiment reference number 02279).

\section{Animals and diets}

Thirty-six growing-finishing crossbreed [(Large white $\times$ Landrace) sows $\times$ Pietrain boar] male pigs were assigned to three equal groups according to their initial liveweight (LW). Pigs were reared at an initial LW of $50.9 \pm 2.4 \mathrm{~kg}$ from 14 to 22 weeks of age and received feed and water ad libitum in individual crates on concrete flooring. Each group was 


\section{ACCEPTED MANUSCRIPT}

fed one of three experimental diets: control (C) containing palm and soybean oils, regular extruded linseed (EL) or low-fiber extruded linseed (EL-). Both types of linseed were produced with a process developed by Valorex (TRADILIN@, Combourtillé, France) consisting in dehulling seeds for low-fiber linseed. Diets respectively contained 0.57, 3.90 and $4.35 \mathrm{~g}$ of ALA per $\mathrm{kg}$ of feed. The three diets contained 2-3\% fat, 18-20\% protein and were supplemented with wheat to be isoenergetic on a net energy basis (Sauvant et al., 2004, Table 1). Since diets followed nutritional recommendations for pigs, amino-acid content did not limit growth. Diets were supplemented with $0.2 \%$ of a premix, whose vitamin E prevented PUFA oxidation. Feed consumption per animal was measured twice a week by subtracting feed refusal from distributed feed quantities. Animals were weighed once a week in the morning and before feed distribution. Before the end of the experiment, one pig on the ELdiet was removed from the experiment due to health problems.

[Table 1, here please]

\section{Slaughter and carcass measurements}

At $114.5 \pm 7.4 \mathrm{~kg}$ LW after 16 hours fasting period, pigs were stunned using electronarcosis and slaughtered by bleeding. After evisceration, the liver, heart and kidneys were removed from the carcass and weighed. The carcass was then cut in half lengthwise and weighed to obtain the total hot weight. Blood and $100 \pm 30 \mathrm{~g}$ of each tissue were sampled to determine the FA composition. Blood was collected during the bleeding. The liver was sampled at the point of the second lobe, whereas the longissimus dorsi (LD) muscle and subcutaneous backfat ( $\mathrm{SCB}$ ) were sampled at the third to last rib on the right side of the carcass. The belly was sampled on the right side of the carcass at the same level as the LD and SCB. Other tissues were sampled along the carcass: subcutaneous adipose tissue in the neck ( $\mathrm{SCN})$ and ham $(\mathrm{SCH})$ (near the tail), internal adipose tissue situated between the gracilis and semitendinosus muscles in ham (IH), some flare fat, the semimembranosus (SM) muscle and the diaphragm. Blood and tissue samples were individually packed and frozen at $-20^{\circ} \mathrm{C}$ until analysis. Carcasses were cooled at $1{ }^{\circ} \mathrm{C}$ for 24 hours and then the $\mathrm{pH}$ of the $\mathrm{LD}$ muscle was measured at the third-to-last rib using a mobile $\mathrm{pH}$-meter. Meat color ( $\mathrm{L}, \mathrm{a}$ and $\mathrm{b}$ parameters) of the LD was measured with a calibrated colorimeter (CR 300, Konica Minolta, France).

\section{Chemical analyses}

Diets were analyzed based on feed sampled each week and were pooled to obtain a sham feeding. Dry matter in diets was measured according to an AFNOR norm (AFNOR, 


\section{ACCEPTED MANUSCRIPT}

1982). Crude protein content was measured according to an ISO norm (ISO, 2008) and crude energy content was measured in an adiabatic bomb calorimeter based on an ISO method (ISO, 1998). Crude fiber content was measured according to the Weende method (Henneberg and Stohman, 1860) and an AFNOR norm (AFNOR, 1993). Acid detergent, neutral detergent fiber and acid detergent lignin contents were determined using the Van Soest method (Van Soest and Wine, 1967).

Fatty acid composition

Lipids in the blood were extracted according to the method of Morrison and Smith, (1964). Lipids in other tissues were cold extracted using chloroform/methanol (v/v 2:1) (Folch et al., 1957). FA methyl esters were saponified with a methanolic sodium hydroxide solution in the presence of C17:0 as the internal FA standard (Agilent Technologies, Santa Clara). They were then methylated with boron trifluoride $\left(\mathrm{BF}_{3}\right)$ (Morrison and Smith, 1964). FA methyl esters were recovered with pentane plus distilled water solution and were analyzed by gas chromatography (7890 GC system, Agilent Technologies, USA). The chromatograph was equipped with a $0.25 \mathrm{~mm} \times 30 \mathrm{~m}$ capillary column made from polysiloxane polymer filled with dimethylpolysiloxane and 50\% cyanopropylphenyl in stationary phase. The temperature program began at $150^{\circ} \mathrm{C}$ and increased $4^{\circ} \mathrm{C}$ per minute up to $220^{\circ} \mathrm{C}$, where it was maintained for 10.5 minutes. Injector and flame-ionization detector temperatures were kept constant at 220 and $280^{\circ} \mathrm{C}$, respectively. Hydrogen was the carrier gas. Retention times and peaks were determined using the chromatography software ChemStation Agilent (Santa Clara, USA). Identities of peaks were verified by comparing peaks to the retention time of standard FA methyl esters. Results were expressed as the percentage of the total FA in diets and as mg per $100 \mathrm{~g}$ of tissue. Total saturated FA (SFA) was the sum of C10:0, C12:0, C14:0, C15:0, C16:0, C18:0, C20:0, C22:0 and C24:0. Total monounsaturated FA (MUFA) was the sum of C14:1, C16:1 (n-7 and n-9), C18:1 (n-7 and n-9), C20:1 n-9, C22:1 (n-9 and n-11) and C24:1. Total PUFA was the sum of n-6 PUFA (C18:2, C18:3, C20:3, C20:4, C22:4 and C22:5), n-3 PUFA (C18:3, C18:4, C20:3, C20:4, C20:5, C22:5 and C22:6) and C20:2.

\section{Statistical analyses}

Data were analyzed using the ANOVA type III (PROC GLM) procedure in SAS® 9.4 with the diet or the tissue as the main factor. Results of performances and tissues FA composition were presented as least-squares means. To compare tissues, multiplecomparisons Bonferroni-test results were presented only when $\mathrm{P}<0.05$. Results were expressed as percentages of total FA. 


\section{ACCEPTED MANUSCRIPT}

\section{Results}

Growth and slaughter performances

The diet had no effect on growth and carcass performances (Table 2).

[Table 2, here please]

\section{Effect of the diet on total lipid content and fatty acid composition in tissues}

Diets had a significant effect on the total lipid content in SM, SCH and IH $(\mathrm{P}<0.05)$ but not in other tissues (Table 3 and 4, Fig 1). They also had a significant effect $(\mathrm{P}<0.05)$ on FA composition of certain muscles and adipose tissues, in which C18:3 n-3 and n-3 PUFA contents were different among the C, EL and EL- diets. C18:3 n-3 and total n-3 PUFA content of LD muscle, diaphragm, SCH and flare fat of pigs fed EL- diet was significantly higher than those of pigs fed EL diet which was also significantly higher than those of pigs fed C diet (Tables 4 and 5).

There was also a significant difference $(P<0.05)$ in FA composition of certain muscles and adipose tissues between the $\mathrm{C}$ diet $v s$ linseed diets. The three subcutaneous adipose tissues (SCN, SCB and SCH) in pigs fed the linseed diets contained significantly less C16:0 than those in pigs fed the $\mathrm{C}$ diet. For MUFA, the $\mathrm{C} 18: 1$ content in the diaphragm and the $\mathrm{IH}$ of pigs fed the linseed diets was lower than those in pigs fed the C diet. Similarly, total MUFA content in the diaphragm, the SCB, the SCH, the belly and the IH in pigs fed the linseed diets was lower than those in pigs fed the $\mathrm{C}$ diet. Total n-6 PUFA content was lower in the plasma and the liver of pigs fed the linseed diets. The C18:3 n-3 content in the SM muscle, the SCN, the belly, the IH, the liver and the blood (plasma + erythrocytes) increased with linseed diets. This was also occurred for other n-3 FA contents, such as those for C20:5 n-3 and n-3 PUFA. Consequently, the linseed diets decreased the n-6/n-3 and C18:3 n6/C18:3 n-3 (LA/ALA) ratios in all the tissues analyzed. Total PUFA content in the diaphragm, the three subcutaneous adipose tissues, the belly and the IH was also higher in pigs fed the linseed diets than those in pigs fed the $\mathrm{C}$ diet (Tables 3, 4 and 5).

[Tables 3, 4 and 5 here please]

[Figure 1, here please]

\section{Effect of muscle location on total lipid content and fatty acid composition}

The diaphragm respectively contained three and four times as much fat as SM and LD muscles, regardless of the diet. The diaphragm contained more saturated and less 


\section{ACCEPTED MANUSCRIPT}

monounsaturated FA than the SM muscle and, to a lesser extent, the LD muscle, regardless of the diet. No statistical difference in C18:2 n-6 content in tissues was observed; however, the diaphragm contained less n-6 PUFA than the SM and LD muscles. The diaphragm had more C18:3 n-3 but less n-3 derivative content (C20:5, C22:5 and C22:6) than the SM and LD muscles, regardless of the diet. It also contained less PUFA than the SM and LD muscles, regardless of the diet (Table 4).

\section{Effect of adipose tissue location on total lipid content and fatty acid composition}

Subcutaneous fat (SCN, SCB and $\mathrm{SCH})$ contained three times as much fat $(63.7 \%)$ as the belly (24.6\%), whereas no difference in total fat was observed in the IH and flare fat, regardless of the diet (Fig. 1).

The belly contained more saturated FA than the SCH and SCN, but less than the SCB, regardless of the diet. These four tissues had the same MUFA content, regardless of the diet. In contrast, the belly contained as much C18:2 n-6 and n- 6 PUFA as the SCB, but less than SCH and SCN, regardless of the diet. The belly also contained less C18:3 n-3 than the three other tissues, regardless of the diet. The C20:5 n-3 content in the SCH was 20-30 times as large as that in the other tissues, depending on the diet. In contrast, all tissues had the same contents of C22:5 and C22:6 n-3, regardless of the diet. The SCH and SCN contained 2-3 percentage points more PUFA than SCB and 3-6 percentage points more PUFA than the belly, depending on the diet (Table 5).

The flare fat contained the most saturated and least monounsaturated FA percentage, regardless of the diet. The FA in $\mathrm{IH}$ were as much saturated as FA in subcutaneous adipose tissues. The belly, the SCB and the flare fat contained less PUFA than the other tissues (Figs. 1 and 2). The flare fat contained as much C18:2 n-6, total n-6 PUFA and C18:3 n-3 as the belly and the SCB, but less than the $\mathrm{IH}, \mathrm{SCN}$ and $\mathrm{SCH}$, regardless of the diet. The $\mathrm{SCH}$ contained the most C20:5 n-3. The SCH contained 30 times as much C20:5 n-3 as other tissues in pigs fed the $\mathrm{C}$ diet, three times as much as other tissues in pigs fed the EL diet and three times as much as the SCB and flare fat in pigs fed the EL- diet. The SCB contained more C22:6 n-3 than the other tissues, regardless of the diet. The belly, SCB and flare fat contained less total n-3 PUFA and total PUFA than the other tissues. The ratio of unsaturated FA/SFA revealed that the SCH and SCN contained the most PUFA, with ratios of 1.65 for the C diet, 1.72-1.82 for the EL diet and 1.82 for the EL- diet, while the flare fat contained the most saturated FA content, with a ratio equal of 1.04 for the $\mathrm{C}$ diet, 1.07 for the EL diet and 1.08 for the EL- diet. However, the largest difference in $n-6 / n-3$ between the $C$ and the linseed 


\section{ACCEPTED MANUSCRIPT}

diets occurred in the SCB and the flare fat, ranging from 10 (C diet) to 2.5 (linseed diets) (Table 5).

[Figure 2, here please]

\section{Discussion}

Effect of dietary fatty acids on growth and carcass performances

Growth and carcass performances were not influenced by the quality of lipids in the diet, which agrees with several studies (Guillevic et al., 2009b; Della Casa et al., 2010; Okrouhlá et al., 2013).

\section{Effect of tissue location and dietary fatty acids on lipid content of tissues}

Our study indicated that the diaphragm contained more fat than the SM and LD muscles, regardless of the diet, which confirmed results of Allen et al., (1967). This difference is due to each muscle's types of muscle fiber and physiological role. The LD muscle, like other ham muscles, is a "white" fast and slow glycolytic contractile muscle, whereas muscle in the anterior part of the body and deep muscles, such as the diaphragm, are considered "red" oxidative low tensing muscles (Lefaucheur et al., 1992). This confirms previous studies that demonstrated that oxidative muscles contain more fat than glycolytic muscles (Cassens and Cooper, 1971; Essén-Gustavsson et al., 1994). The total lipid content found in the flare fat was the same as that in Monziols et al., (2007), despite using different breeds.

Unlike for the SM muscle, FA composition in the diet did not influence lipid content in the LD muscle and the diaphragm, which is confirmed by other studies of pigs and cows (Mourot et al., 1995; Habeanu et al., 2014). The diet had no effect on the lipid content of other subcutaneous adipose tissues, except the SCH. Other pig studies confirm this observation for the SCB (Kouba et al., 2003; Wilfart et al., 2004; Corino et al., 2008). Similarly, FA composition in the diet did not influence lipid content in the flare fat or the IH. These results are confirmed by the studies in pig and rabbit flare fat composition (Kouba et al., 2008; Benatmane et al., 2011) and pig ham composition (Musella et al., 2009).

\section{Effect of tissue location and dietary fatty acids on fatty acid composition in tissues}

The diaphragm contained more SFA but less MUFA and PUFA than the SM and LD muscles, regardless of the diet. This result disagrees with the study of Malmfors et al. (1978), who found that quadriceps femoris, a "red" muscle, contained 6-7\% more PUFA than the LD muscle (in Bout and Girard, 1988). As a skeletal muscle, the diaphragm can adapt its 


\section{ACCEPTED MANUSCRIPT}

metabolism to the environment such as nutrient availability. For example, it can replace glucose by long chain FA (LCFA) to provide energy during short-term starvation (24-48h). In our experiment, pigs fasted 16 hours before slaughter, which seems sufficient to decrease MUFA and PUFA contents in the diaphragm. MUFA and PUFA, which are LCFA, supplied energy to the diaphragm. Given the diaphragm's function, we hypothesized that n-3 PUFA enter diaphragm muscle cells as phospholipids rather than neutral lipids, which increases nutrient exchange in the diaphragm (Bout and Girard, 1988). The diaphragm seems less able to capture n-3 PUFA derivatives than the other two muscles. Indeed, it contained more C18:3 n-3 and less C20:5, C22:5 and C22:6 n-3 than the LD and SM muscles, regardless of the diet.

Analysis of FA composition in the subcutaneous adipose tissue revealed a larger percentage of SFA in the middle of the carcass (SCB and belly). In contrast, the front and back ends of the carcass (SCN and SCH), contained more PUFA, especially n-3 and n-6 FA, than the middle. This could be because the SCB and belly synthesize SFA, while the SCN and to a lesser extent the SCH store SFA. The review of Mourot et al., (1999), demonstrated that the SCB and the belly have greater lipogenesis capacity than the SCN. Among adipose tissues, the flare fat contained the largest percentage of SFA, regardless of the diet. This confirmed results of Girard et al., (1988), who found that the content of SFA in the flare fat (52\%) was larger than in the SCB (42\%). According to Mourot et al., (1999), the intensity of lipogenesis varied in adipose tissues as a function of anatomical location. It is higher in flare fat than in other adipose tissues ( $\mathrm{SCH}, \mathrm{SCB}$, belly, $\mathrm{IH}$, intermuscular fat in the shoulder, SCN and subcutaneous fat in the throat). Flare fat contained the smallest percentage of MUFA, which is also confirmed by Girard et al., (1988). MUFA content in adipose tissues follows a gradient: highest in the outer layer of subcutaneous adipose tissue, followed by its inner layer, intermuscular fat and flare fat (Monziols et al., 2007). The flare fat, belly and SCB contained less C18:2 n-6, n-6 PUFA, C18:3 n-3, n-3 PUFA and PUFA than the other tissues (IH, SCN and $\mathrm{SCH}$ ), confirming that the flare fat contains a smaller percentage of PUFA. The SCH seems to be the preferred tissue for C20:5 n-3 storage, while the SCB contained more C22:6 n-3 than the other adipose tissues.

Diet also had an effect on FA composition of the tissues. Compared to the EL diet, the EL- diet increased deposition of C18:3 n-3 by $18 \%$ in the LD muscle, which is consumed as fresh meat as roast or with the rib in France. Consequently, 100g of a cooked pork rib from pigs fed the EL and EL- diets provide $11.6 \%$ and $13.1 \%$ of daily ALA requirements ( $2 \mathrm{~g}$ per day for adult consuming $2000 \mathrm{kcal}$ per day; Anses, 2011), respectively. Thus, muscles products from pigs fed the EL- diet provide more nutritional benefit than those from pigs fed 


\section{ACCEPTED MANUSCRIPT}

the EL diet. The deposition of C18:3 n-3 in the diaphragm also increased (by 19\%) with the EL- diet compared to the EL diet, but did not increase in the SM muscle.

The linseed diets increased contents of C20:5 n-3, a derivative of C18:3 n-3, in the LD an SM muscles and diaphragm. The low C22:6 n-3 content agrees with results of Brenna (2002) and Burdge and Calder (2005). This is due to the low conversion rate of C18:3 n-3 to C22:6 n-3 (1\%). Conversely, the conversion rate of ALA to C20:5 n-3 is higher $(\approx 5 \%)$ than that of ALA to C22:6 n-3 (Plourde and Cunnane, 2007).

Feeding pigs linseed diets decreased C16:0, SFA and MUFA contents; increased C20:5 n-3 and PUFA contents; and had no effect on C22:6 n-3 contents in the three dorsal subcutaneous adipose tissues. Similarly, the linseed diets decreased MUFA content and increased C18:3 n3, n-3 PUFA and PUFA contents in the belly, but did not influence other FA contents. Regarding SFA content, a decrease in FA synthase activity, which is involved in lipogenesis, in the SCB due to a supply of dietary n-3 PUFA could explain the lower deposition of these FA in adipose tissue (De Tonnac et al., 2016). Lipogenesis activity, which occurs mainly in adipose tissues after weaning, decreased as the supply of linseed increases (Guillevic et al., 2009b; Benatmane et al., 2011). According to our experiment, this seems true for dorsal but not for ventral adipose tissues. Regarding MUFA content, decreasing activity of $\Delta 9$ desaturase, which generates MUFA from SFA, after linseed supplied in the pig diet could explain the lower contents of these FA in dorsal subcutaneous adipose tissues (Kouba et al., 2003; Guillevic et al., 2009b). Decreasing the fiber content of the linseed increased C18:3 n-3 and n-3 PUFA deposition by $9 \%$ in the SCB and the SCH compared to that the EL diet. The high n-3 PUFA content in the SCB, SCH and belly of pigs fed linseed is due to the latter's significantly higher content of C18:3 n-3. The C20:5 and C22:6 n-3 content in the SCB and SCH did not differ between linseed diets, showing the limited ability of these tissues to capture or synthesize n-3 PUFA derivatives. The C16:0 and SFA contents in the IH and flare fat were not influenced by diets (Guillevic et al., 2009a). In contrast, C18:3 n-3 content in the flare fat and IH increased significantly when linseed was supplied in the diet. However, only C18:3 n-3 and n-3 PUFA contents in flare fat, but not in the IH in pigs fed EL- were significantly higher than those in pigs fed EL diet. Compared to the EL diet, the EL- diet increased C18:3 n-3 content in flare fat by $17 \%$ but did not increase flare fat's contents of n-3 PUFA derivatives, such as C20:5 and C22:6. This result disagreed with Guillevic et al., (2009a), who found that C20:5 n-3 content in leaf fat increased when linseed was supplied in the diet. In contrast, C20:5 n-3 content, but not C22:6 n-3 content in the IH increased significantly when linseed was supplied in the diet, which is confirmed by the study of 


\section{ACCEPTED MANUSCRIPT}

Musella et al., (2009). The IH seems to have a greater ability than flare fat to capture C20:5 n3 which most likely comes from the liver.

\section{Metabolism of fatty acids}

No significant differences in FA composition in the blood (plasma and erythrocytes) and liver were observed between the EL and EL- diets. However, the linseed diets decreased n-6 PUFA in the liver due to a decrease in C18:3, C20:4, C22:4 and C22:5 n-6 (data not shown) (Matthews et al., 2000; D’Arrigo et al., 2002; Duran-Montge et al., 2009). They also decreased n-6 PUFA in the plasma (Kouba et al., 2003). These results confirm the competition between n-6 and n-3 families for $\Delta 6$ desaturase (de Antueno et al., 2001). In our experiment, this enzyme synthesized mostly C20:5 n-3 from C18:3 n-3 at the expense of n-6 PUFA derivatives from C18:2 n-6. The linseed diets increased C18:3 n-3 in the blood (Matthews et al., 2000; Kouba et al., 2003), even though pigs were fasted for 16 hours before slaughter. This result indicates that exogenous FA in diets are transported from the blood to tissues a long time after feeding. Linseed diets also increased C20:5 n-3 and n-3 PUFA content in the blood (Matthews et al., 2000; Kouba et al., 2003) and the liver (Matthews et al., 2000; D'Arrigo et al., 2002; Duran-Montge et al., 2009). Nonhepatic tissues capture endogenous FA from the liver. Because of low $\Delta 6$-desaturase activity in these tissues, the liver products most of the long chain polyenoic FA used by peripheral tissues (Scott and Bazan, 1989; Bourre et al., 1990; Cho et al., 1999), which explains why peripheral tissues and the liver had similar FA composition. It has also been demonstrated that diets rich in vegetable or marine oils supress hepatic $\Delta 6$-desaturase activity (Peluffo et al., 1976; Melin and Nilsson, 1997). Gene expression of this enzyme also decreased when an n-3 PUFA rich diet was supplied (De Tonnac et al., 2016), which could explain the limited capacity to synthesize n-3 PUFA derivatives, such as C22:6 n-3 from C18:3 n-3. In contrast, linseed diets had no effect on C16:0, C18:0 and SFA contents in the blood and liver. This result is suprising in the liver, because lipogenic enzymes activities (FA synthase, malic enzyme and glucose-6-dehydrogenase) decreased in pig and rabbit tissues when n-3 PUFA was supplied in the diet (Guillevic et al., 2009b; Benatmane et al., 2011; De Tonnac et al., 2016).

\section{Conclusion}

In this study, we compared effects of regular and low-fiber extruded linseed diets on FA deposition, especially C18:3 and n-3 PUFA, in several pig tissues. The objective of these diets was to enrich several tissues with dietary n-3 PUFA. First, for a given tissue, the n-6/n-3 ratio was lower when pigs were fed a linseed diet rather than a control diet. The diaphragm 


\section{ACCEPTED MANUSCRIPT}

contained higher content of C18:3 n-3 but lower content of n-3 PUFA derivatives than the LD and SM muscles, thus showing lower capacity to capture the n-3 PUFA derivatives. Similarly, adipose tissues such as SCN, SCH and the IH contained more C18:3 n-3 than belly, SCB and flare fat. Nevertheless, the SCB was the adipose tissue richest in $\mathrm{C} 22: 6 \mathrm{n}-3$, whereas the SCH was the richest in C20:5 n-3. The SCB and the belly contained more SFA than other adipose tissues, but the flare fat had the most, revealing their high lipogenesis capacity. Depending on the FA composition, these results confirmed the benefit of feeding animals well to improve human health. Second, the supply of EL- diet significantly increases the deposition of C18:3 and n-3 PUFA in certain muscles (LD and diaphragm), subcutaneous (SCB and SCH) and internal (flare fat) adipose tissues compared to EL diet, but effects of the linseed diets did not differ significantly in the blood or the liver. This effect increased deposition of C18:3 n-3 derivatives, such as C20:5 n-3, but not C22:6 n-3 in muscles (LD, SM and diaphragm), adipose tissues (SCN, SCB and $\mathrm{IH}$ ), blood and liver compared to that in the control diet. Consequently, there is a nutritional benefit to feeding pigs with EL- diet and this benefit is not hindered by economic concerns, since the EL- diet costs only $2 €$ more per ton than the EL diet.

\section{Conflict of Interest Statement}

All authors read and approved the final version of the manuscript. The authors have no financial or personal conflicts of interest to declare.

\section{Acknowledgements}

This work was supported by the National Research Agency and conducted within the national AGRALID project (Project ANR 12-ALID-003). The authors wish to acknowledge the technical or temporary staff at the INRA laboratory for their skilled assistance, especially Sihem Karim-Lhuisset. We also thank Valorex for providing the linseed. All authors read and approved the final version of the manuscript. The authors have no financial or personal conflicts of interest to declare.

\section{References}

AFNOR, 1982. Animal feed. Determination of water content., NF V18-109, p. 5.

AFNOR, 1993. Animal feeding stuffs and animal products - Determination of crude cellulose method. NF V03-040, p. 12.

Allen, E., Cassens, R.G., Bray, R.W., 1967. Comparative lipid content of three porcine muscles. J. Anim. Sci. 32, 20-25. 


\section{ACCEPTED MANUSCRIPT}

Anses, 2011. Actualisation des apports nutritionnels conseillés pour les acides gras [Updating recommended dietary intakes for fatty acids]. p. 323.

Benatmane, F., Kouba, M., Youyou, A., Mourot, J., 2011. Effect of a linseed diet on lipogenesis, fatty acid composition and stearoyl-CoA-desaturase in rabbits. Animal 5, 1993 2000 .

Bourre, J.M., Piciotli, M., Dumont, O., 1990. $\Delta 6$ Desaturase in Brain and Liver During Development and Aging. Lipids 25, 354-356.

Bout, J., Girard, J.P., 1988. Lipides et qualité du tissu musculaire, facteurs de variation [Lipids and muscle tissue quality, variation factors]. Journées Rech. Porcine, pp. 271-278.

Brenna, J.T., 2002. Efficiency of conversion of alpha-linolenic acid to long chain n-3 fatty acids in man. Curr. Opin. Clin. Nutr. Metab. Care 5, 127-132.

Burdge, G.C., Calder, P.C., 2005. Conversion of alpha-linolenic acid to longer-chain polyunsaturated fatty acids in human adults. Reprod. Nutr. Dev. 45, 581-597.

Cassens, R.G., Cooper, C.C., 1971. Red and white muscle. Adv. Food Res. 19, 1-74.

Cho, H.P., Nakamura, M.T., Clarke, S.D., 1999. Cloning, Expression, and Nutritional Regulation of the Mammalian D-6 Desaturase. J. Biol. Chem. 274, 471-477.

Corino, C., Musella, M., Mourot, J., 2008. Influence of extruded linseed on growth, carcass composition, and meat quality of slaughtered pigs at one hundred ten and one hundred sixty kilograms of liveweight. J. Anim. Sci. 86, 1850-1860.

D’Arrigo, M., Hoz, L., Lopez-Bote, C.J., Cambero, I., Pin, C., Ordonez, J.A., 2002. Effect of dietary linseed oil on pig hepatic tissue fatty acid composition and susceptibility to lipid peroxidation. Nutr. Res. 22, 1189-1196.

de Antueno, R.J., Knickle, L.C., Smith, H., Elliot, M.L., Allen, S.J., Nwaka, S., Winther, M.D., 2001. Activity of human Delta5 and Delta6 desaturases on multiple n-3 and n-6 polyunsaturated fatty acids. FEBS Letters 509, 77-80.

De Tonnac, A., Labussiere, E., Vincent, A., Mourot, J., 2016. Effect of alpha-linolenic acid and DHA intake on lipogenesis and gene expression involved in fatty acid metabolism in growing-finishing pigs. Br. J. Nutr. 116, 7-18.

Della Casa, G., Bochicchio, D., Faeti, V., Marchetto, G., Poletti, E., Rossi, A., Panciroli, A., Mordenti, A.L., Brogna, N., 2010. Performance and fat quality of heavy pigs fed maize differing in linoleic acid content. Meat Sci. 84, 152-158.

Duran-Montge, P., Theil, P.K., Lauridsen, C., Esteve-Garcia, E., 2009. Fat metabolism is regulated by altered gene expression of lipogenic enzymes and regulatory factors in liver and adipose tissue but not in semimembranosus muscle of pigs during the fattening period. Animal 3, 1580-1590.

Essén-Gustavsson, B., Karlsson, A., Lundström, K., Enfält, A.-C., 1994. Intramuscular Fat and Muscle Fibre Lipid Contents in Halothane-Gene-Free Pigs Fed High or Low Protein Diets and its Relation to Meat Quality. Meat Sci. 38, 269-277.

Folch, J., Lees, M., Sloane Stanley, G.H., 1957. A simple method for the isolation and purification of total lipides from animal tissues. J. Biol. Chem. 226, 497-509.

Girard, J.P., Bout, J., Salort, J., 1988. Lipides et qualité des tissus adipeux et musculaires de porc facteurs de variation. 1ère partie : Lipides et qualités du tissu adipeux [Lipids and adipose tissue quality, variation factors]. Journées Rech. Porcine, pp. 255-278. 
Guillevic, M., Kouba, M., Mourot, J., 2009a. Effect of a linseed diet on lipid composition, lipid peroxidation and consumer evaluation of French fresh and cooked pork meats. Meat Sci. 81, 612-618.

Guillevic, M., Kouba, M., Mourot, J., 2009b. Effect of a linseed diet or a sunflower diet on performances, fatty acid composition, lipogenic enzyme activities and stearoyl-CoAdesaturase activity in the pig. Livest. Sci. 124, 288-294.

Habeanu, M., Thomas, A., Bispo, E., Gobert, M., Gruffat, D., Durand, D., Bauchart, D., 2014. Extruded linseed and rapeseed both influenced fatty acid composition of total lipids and their polar and neutral fractions in longissimus thoracis and semitendinosus muscles of finishing Normand cows. Meat Sci. 96, 99-107.

Henneberg, W., Stohman, F., 1860. Begründung einer rationellen Fütterung des Wiederkäuer. In: sohn, C.A.S.u. (Ed.).

ISO, 1998. Animal feeding stuffs, animal products, and faeces or urine - Determination of gross calorific value - Bomb calorimeter method. ISO 9831:1998, p. 23.

ISO, 2008. Food products-Determination of total nitrogen content by combustion according to the Dumas principle and calculation of crude protein content. Part 1: oilseeds and animal feed. ISO 16634-1:2008 p. 30.

Kloareg, M., Noblet, J., van Milgen, J., 2007. Deposition of dietary fatty acids, de novo synthesis and anatomical partitioning of fatty acids in finishing pigs. Br. J. Nutr. 97, 35-44.

Kouba, M., Benatmane, F., Blochet, J.E., Mourot, J., 2008. Effect of a linseed diet on lipid oxidation, fatty acid composition of muscle, perirenal fat, and raw and cooked rabbit meat. Meat Sci. 80, 829-834.

Kouba, M., Enser, M., Whittington, F.M., Nute, G.R., Wood, J.D., 2003. Effect of a highlinolenic acid diet on lipogenic enzyme activities, fatty acid composition, and meat quality in the growing pig. J. Anim. Sci. 81, 1967-1979.

Lefaucheur, L., Missohou, A., Ecolan, P., Monin, G., Bonneau, M., 1992. Performance, Plasma Hormones, Histochemical and Biochemical Muscle Traits, and Meat Quality of Pigs Administered Exogenous Somato tropin Between 30 or 60 Kilograms and 100 Kilograms Body Weight. J. Anim. Sci. 70, 3401-3411.

Matthews, K.R., Homer, D.B., Thies, F., Calder, P.C., 2000. Effect of whole linseed (Linum usitatissimum) in the diet of finishing pigs on growth performance and on the quality and fatty acid composition of various tissues. Br. J. Nutr. 83, 637-643.

Melin, T., Nilsson, A., 1997. Delta-6-desaturase and delta.5. desaturase in human Hep G2 cells are both fatty acid interconversion rate limiting and are upregulated under essential fatty acid deficient conditions. Prostaglandins Leukot. Essent. Fatty Acids 56, 437-442.

Monziols, M., Bonneau, M., Davenel, A., Kouba, M., 2007. Comparison of the lipid content and fatty acid composition of intermuscular and subcutaneous adipose tissues in pig carcasses. Meat Sci. 76, 54-60.

Morrison, W.R., Smith, L.M., 1964. Preparation of fatty acid methyl esters and dimethyl acetals from lipids with boron fluoride methanol. J. Lipid Res. 5, 600-608.

Mourot, J., de Tonnac, A., 2015. The Bleu Blanc Coeur path: impacts on animal products and human health. OCL 22, D610.

Mourot, J., Hermier, D., 2001. Lipids in monogastric animal meat. Reprod. Nutr. Dev. 41, 109-118. 


\section{ACCEPTED MANUSCRIPT}

Mourot, J., Kouba, M., Salvatori, G., 1999. Facteurs de variation de la lipogenèse dans les adipocytes et les tissus adipeux chez le porc [Variation of lipogenesis in pig adipocytes and adipose tissues]. INRA Prod. Anim. 12, 311-318.

Mourot, J., Kouba, M., Peiniau, P., 1995. Comparative study of in vitro lipogenesis in various adipose tissues in the growing domestic pig (Sus domesticus). Comp. Biochem. Physiol. 111B, 379-384.

Musella, M., Cannata, S., Rossi, R., Mourot, J., Baldini, P., Corino, C., 2009. Omega-3 polyunsaturated fatty acid from extruded linseed influences the fatty acid composition and sensory characteristics of dry-cured ham from heavy pigs. J. Anim. Sci. 87, 3578-3588.

Noblet, J., Jaguelin-Peyraud, Y., Quemeneur, B., Chesneau, G., 2008. Valeur énergétique de la graine de lin chez le porc : impact de la technologie de cuisson-extrusion [Energy value of linseed in pigs: impact of extrusion technology]. Journées Rech. Porcine, pp. 203-208.

Okrouhlá, M., Stupka, R., Čítek, J., Šprysl, M., Brzobohatý, L., 2013. Effect of dietary linseed supplementation on the performance, meat quality, and fatty acid profile of pigs. Czech J. Anim. Sci 58, 279-288.

Peluffo, R.O., Nervi, A.M., Brenner, R.R., 1976. Linoleic acid desaturation activity of liver microsomes of essential fatty acid deficient and sufficient rats. Biochim. Biophys. Acta 441, 25-31.

Plourde, M., Cunnane, S.C., 2007. Extremely limited synthesis of long chain polyunsaturates in adults: implications for their dietary essentiality and use as supplements. App. Physiol. Nutr. Metab. 32, 619-634.

Sauvant, D., Perez, J.M., Tran, G., 2004. Tables of composition and nutritional value of raw materials for livestock. p. 304.

Scott, B.L., Bazan, N.G., 1989. Membrane docosahexaenoic is supplied to the developing brain and retina by the liver. Proc. Natl. Acad. Sci. 86, 2903-2907.

Van Soest, P.J., Wine, R.H., 1967. Use of detergents in the analysis of fibrous feeds. IVDetermination of plant cell walls constituents. J. Assoc. Agric. Chem 50, 50-55.

Wilfart, A., Ferreira, J.M., Mounier, A., Robin, G., Mourot, J., 2004. Effet de différentes teneurs en acides gras n-3 sur les performances de croissance et la qualité nutritionnelle de la viande de porc [Effect of different n-3 fatty acid content on the nutritional quality of pork]. Journées Rech. Porcine, pp. 195-202.

Table 1. Ingredient (\% fresh), analyzed chemical composition (\% DM) and analyzed fatty acids profile (\% total fatty acids) of the diets

\begin{tabular}{lccc}
\hline & $\mathrm{C}$ & $\mathrm{EL}$ & EL- \\
\hline Ingredient composition & & & \\
Wheat & 24.4 & 23.0 & 22.8 \\
Maize & 24.4 & 23.0 & 22.8 \\
Barley & 24.4 & 23.0 & 22.8 \\
Soya meal 48 & 17.9 & 18.6 & 18.7 \\
Wheat bran & 2.5 & 2.5 & 2.6 \\
Palm oil & 0.2 & - & - \\
Soya oil & 0.2 & - & - \\
Extruded linseed & - & 3.6 & -
\end{tabular}


Extruded and dehulled linseed $\quad-\quad-\quad-\quad-\quad 4.1$

\begin{tabular}{|c|c|c|c|}
\hline \multicolumn{3}{|c|}{ Cane molasses CETED MA N 3.0 DP 3.0} & \multirow{2}{*}{$\begin{array}{l}3.0 \\
0.3\end{array}$} \\
\hline L-Lysine HCL & 0.3 & 0.3 & \\
\hline L-Threonine & 0.1 & 0.1 & 0.1 \\
\hline L-Tryptophane & 0.01 & 0.01 & 0.01 \\
\hline DL-Methionine & 0.05 & 0.05 & 0.05 \\
\hline Salt & 0.5 & 0.5 & 0.5 \\
\hline Calcium carbonate & 0.5 & 0.5 & 0.5 \\
\hline Dicalcium phosphate & 1.0 & 1.0 & 1.0 \\
\hline Premix & 0.7 & 0.7 & 0.7 \\
\hline \multicolumn{4}{|l|}{ Chemical composition } \\
\hline $\mathrm{DM}(\%)$ & 84.35 & 85.39 & 85.50 \\
\hline $\begin{array}{l}\text { Gross energy } \\
(\mathrm{MJ} / \mathrm{kg} \text { of } \mathrm{DM})\end{array}$ & 18.04 & 18.11 & 18.31 \\
\hline $\begin{array}{l}\text { Net energy } \\
(\mathrm{MJ} / \mathrm{kg})\end{array}$ & 9.82 & 11.61 & 11.67 \\
\hline Crude protein & 20.29 & 18.65 & 19.37 \\
\hline Fat & 2.05 & 2.90 & 3.29 \\
\hline Crude fiber & 3.50 & 3.51 & 3.57 \\
\hline $\mathrm{NDF}$ & 13.76 & 14.11 & 14.02 \\
\hline $\mathrm{ADF}$ & 4.40 & 4.22 & 4.47 \\
\hline ADL & 0.68 & 0.62 & 0.66 \\
\hline Total sugars & 2.67 & 2.56 & 4.64 \\
\hline \multicolumn{4}{|l|}{ Fatty acids } \\
\hline C16:0 & 16.05 & 12.38 & 12.09 \\
\hline C18:0 & 2.18 & 2.49 & 2.51 \\
\hline C18:1 n-9 & 22.54 & 18.22 & 18.03 \\
\hline C18:2 n-6 & 52.65 & 44.01 & 43.69 \\
\hline C18:3 n-3 & 3.51 & 20.72 & 21.59 \\
\hline$C 20: 5 n-3$ & 0.10 & 0.08 & 0.06 \\
\hline$C 22: 5 n-3$ & 0.00 & 0.00 & 0.00 \\
\hline$C 22: 6 n-3$ & 0.03 & 0.01 & 0.01 \\
\hline SFA & 19.24 & 15.65 & 15.34 \\
\hline MUFA & 24.18 & 19.39 & 19.20 \\
\hline PUFA & 56.58 & 64.95 & 65.47 \\
\hline$n-3$ & 3.86 & 20.90 & 21.73 \\
\hline$n-6$ & 52.68 & 44.01 & 43.69 \\
\hline$n-6 / n-3$ & 13.67 & 2.11 & 2.01 \\
\hline
\end{tabular}

$\mathrm{C}=$ control diet, $\overline{\mathrm{EL}}=$ extruded linseed diet, $\mathrm{EL}-=\mathrm{EL}$ poor fiber diet, DM dry matter, NDF neutral detergent fiber, ADF acid detergent fiber, ADL acid detergent lignin, SFA = sum of saturated fatty acids, MUFA = sum of monounsaturated fatty acids, PUFA = sum of polyunsaturated fatty acids, $n-6 / n-3=$ sum of n-6 fatty acids/sum of n-3 fatty acids ratio. Premix was composed by $\alpha$-tocopherol acetate, $0.2 \%$ magnesium, 26.7\% calcium, vitamin A, D3, B1, B2, B6 and E, pantothenic acid, iron, copper and zinc. 


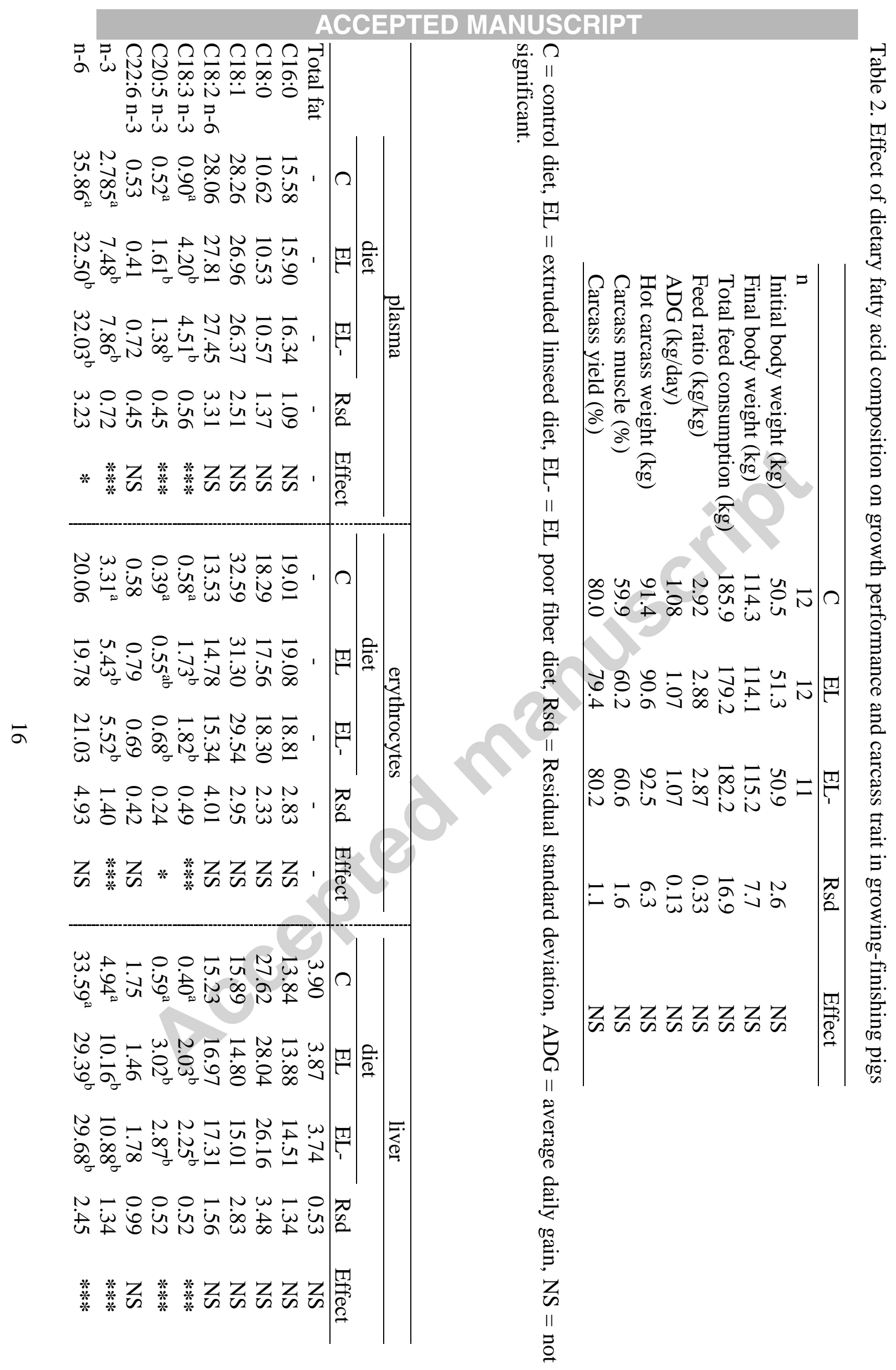




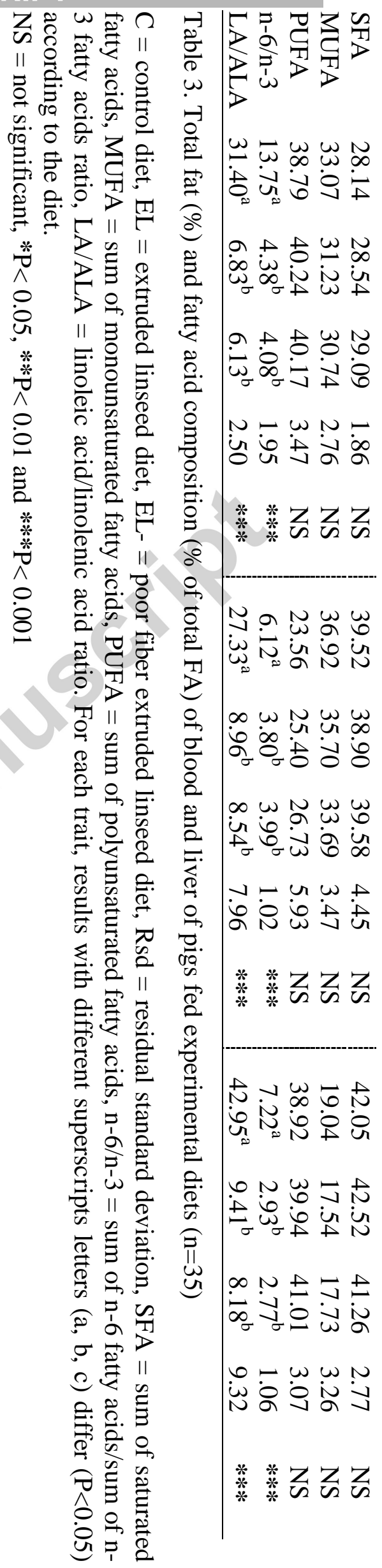


Table 4. Total fat (\%) and fatty acid content (\% of total FA) of muscles (semimembranosus, longissimus dorsi and diaphragm) of pigs fed experimental diets $(\mathrm{n}=35)$ USCR\|PT

\begin{tabular}{|c|c|c|c|c|}
\hline & diet & SM & $\mathrm{LD}$ & diaphragm \\
\hline & $\mathrm{C}$ & $2.36^{\mathrm{ax}}$ & $1.48^{\mathrm{a}}$ & $6.83^{\mathrm{b}}$ \\
\hline \multirow[t]{2}{*}{ Total fat } & EL & $1.85^{\mathrm{ay}}$ & $1.52^{\mathrm{a}}$ & $6.19^{\mathrm{b}}$ \\
\hline & EL- & $1.99^{\text {axy }}$ & $1.68^{\mathrm{a}}$ & $5.57^{\mathrm{b}}$ \\
\hline & $\mathrm{C}$ & $22.22^{\mathrm{a}}$ & $23.45^{\mathrm{a}}$ & $25.00^{\mathrm{b}}$ \\
\hline \multirow[t]{3}{*}{ C16:0 } & EL & $21.60^{\mathrm{a}}$ & $23.02^{\mathrm{b}}$ & $24.25^{\mathrm{b}}$ \\
\hline & EL- & $21.50^{\mathrm{a}}$ & $22.79^{\mathrm{ab}}$ & $23.82^{\mathrm{b}}$ \\
\hline & $\bar{C}$ & $11.45^{\mathrm{a}}$ & $11.87^{\mathrm{a}}$ & $16.69^{b}$ \\
\hline \multirow[t]{3}{*}{ C18:0 } & EL & $10.98^{\mathrm{a}}$ & $12.37^{\mathrm{b}}$ & $17.08^{\mathrm{c}}$ \\
\hline & EL- & $10.89^{\mathrm{a}}$ & $12.08^{\mathrm{b}}$ & $16.79^{c}$ \\
\hline & $\mathrm{C}$ & $40.39^{\mathrm{a}}$ & $38.56^{\mathrm{ab}}$ & $38.09^{\mathrm{bx}}$ \\
\hline \multirow[t]{3}{*}{ C18:1 } & EL & $39.01^{\mathrm{a}}$ & $37.79^{\mathrm{a}}$ & $36.06^{\text {by }}$ \\
\hline & EL- & $39.61^{\mathrm{a}}$ & $37.12^{\mathrm{ab}}$ & $34.93^{\text {by }}$ \\
\hline & $\mathrm{C}$ & 11.18 & 11.21 & $9.86^{x}$ \\
\hline \multirow[t]{3}{*}{$C 18: 2$ n-6 } & EL & 12.39 & 11.36 & $10.59^{x y}$ \\
\hline & EL- & 12.15 & 12.20 & $11.96^{\mathrm{y}}$ \\
\hline & $\mathrm{C}$ & $0.58^{\mathrm{abx}}$ & $0.48^{\mathrm{ax}}$ & $0.60^{\mathrm{bx}}$ \\
\hline \multirow[t]{2}{*}{ C18:3 n-3 } & EL & $1.92^{\mathrm{ay}}$ & $1.68^{\text {ay }}$ & $2.48^{\text {by }}$ \\
\hline & EL- & $2.03^{\mathrm{ay}}$ & $1.99^{\mathrm{az}}$ & $2.96^{\mathrm{bz}}$ \\
\hline \multirow{3}{*}{$C 20: 5 n-3$} & $\mathrm{C}$ & $0.15^{\mathrm{ax}}$ & $0.16^{\mathrm{ax}}$ & $0.05^{\mathrm{bx}}$ \\
\hline & EL & $0.52^{\mathrm{ay}}$ & $0.51^{\text {ay }}$ & $0.18^{\text {by }}$ \\
\hline & EL- & $0.48^{\text {ay }}$ & $0.55^{\text {ay }}$ & $0.22^{\text {by }}$ \\
\hline \multirow{3}{*}{$C 22: 5 n-3$} & $\mathrm{C}$ & $0.34^{\mathrm{ax}}$ & $0.41^{\mathrm{ax}}$ & $0.15^{\mathrm{bx}}$ \\
\hline & EL & $0.70^{\text {ay }}$ & $0.76^{\mathrm{ay}}$ & $0.36^{\text {by }}$ \\
\hline & EL- & $0.66^{\text {ay }}$ & $0.83^{\text {ay }}$ & $0.39^{\text {by }}$ \\
\hline \multirow{3}{*}{$C 22: 6 n-3$} & $\mathrm{C}$ & $0.22^{\mathrm{a}}$ & $0.28^{\mathrm{a}}$ & $0.07^{\mathrm{b}}$ \\
\hline & EL & $0.20^{\mathrm{a}}$ & $0.27^{\mathrm{b}}$ & $0.08^{c}$ \\
\hline & EL- & $0.20^{\mathrm{a}}$ & $0.29^{\mathrm{b}}$ & $0.09^{c}$ \\
\hline \multirow{3}{*}{$n-3$} & $\mathrm{C}$ & $1.56^{\mathrm{ax}}$ & $1.49^{\mathrm{ax}}$ & $1.09^{\mathrm{bx}}$ \\
\hline & EL & $3.91^{\mathrm{y}}$ & $3.62^{\mathrm{y}}$ & $3.56^{\mathrm{y}}$ \\
\hline & EL- & $3.96^{\mathrm{y}}$ & $4.09^{\mathrm{y}}$ & $4.19^{\mathrm{z}}$ \\
\hline \multirow{3}{*}{$n-6$} & $\mathrm{C}$ & $14.30^{\mathrm{ab}}$ & $14.97^{\mathrm{a}}$ & $11.32^{b}$ \\
\hline & EL & $15.07^{\mathrm{a}}$ & $14.15^{\mathrm{ab}}$ & $11.79^{\mathrm{b}}$ \\
\hline & EL- & 14.64 & 15.13 & 13.24 \\
\hline \multirow{3}{*}{ SFA } & $\mathrm{C}$ & $35.40^{\mathrm{a}}$ & $36.83^{\mathrm{a}}$ & $43.36^{b}$ \\
\hline & EL & $34.08^{\mathrm{a}}$ & $36.89^{\mathrm{b}}$ & $42.97^{\mathrm{c}}$ \\
\hline & EL- & $33.82^{\mathrm{a}}$ & $36.29^{\mathrm{b}}$ & $42.17^{\mathrm{c}}$ \\
\hline \multirow{3}{*}{ MUFA } & $\mathrm{C}$ & $48.35^{\mathrm{a}}$ & $46.41^{\mathrm{ab}}$ & $43.86^{b x}$ \\
\hline & EL & $46.53^{\mathrm{a}}$ & $45.00^{\mathrm{a}}$ & $41.29^{\text {by }}$ \\
\hline & EL- & $47.16^{\mathrm{a}}$ & $44.15^{\mathrm{a}}$ & $39.96^{\text {by }}$ \\
\hline \multirow{3}{*}{ PUFA } & $\mathrm{C}$ & $16.25^{\mathrm{ab}}$ & $16.76^{\mathrm{a}}$ & $12.78^{\mathrm{bx}}$ \\
\hline & EL & $19.40^{\mathrm{a}}$ & $18.10^{\mathrm{ab}}$ & $15.74^{\text {by }}$ \\
\hline & EL- & 19.02 & 19.56 & $17.87^{\mathrm{y}}$ \\
\hline \multirow{3}{*}{$n-6 / n-3$} & $\mathrm{C}$ & $9.18^{\mathrm{ax}}$ & $10.10^{\mathrm{abx}}$ & $10.42^{\mathrm{bx}}$ \\
\hline & EL & $3.84^{\mathrm{ay}}$ & $3.91^{\mathrm{ay}}$ & $3.30^{\text {by }}$ \\
\hline & EL- & $3.71^{\text {ay }}$ & $3.69^{\text {ay }}$ & $3.16^{\text {by }}$ \\
\hline \multirow{3}{*}{ LA/ALA } & $\mathrm{C}$ & $19.31^{\mathrm{ax}}$ & $23.76^{\mathrm{bx}}$ & $16.46^{\mathrm{ax}}$ \\
\hline & EL & $6.48^{\mathrm{ay}}$ & $6.80^{\mathrm{ay}}$ & $4.27^{\text {by }}$ \\
\hline & EL- & $6.03^{\mathrm{ay}}$ & $6.14^{\mathrm{ay}}$ & $4.07^{\text {by }}$ \\
\hline
\end{tabular}

$\mathrm{C}=$ control diet, $\mathrm{EL}=$ extruded linseed diet, $\mathrm{EL}-=$ poor fiber extruded linseed diet, SFA $=$ saturated fatty acids, MUFA $=$ monounsaturated fatty acids, PUFA $=$ polyunsaturated fatty acids, SFA $=$ sum of SFA, MUFA $=$ sum of MUFA, PUFA $=$ sum of PUFA, $n-6 / n-3=$ sum of $n-6$ fatty acids/sum of $n-3$ fatty acids ratio, LA/ALA = linoleic 
acid/linolenic acid ratio. For each line, results with different superscripts letters $(a, b, c)$ differ $(\mathrm{P}<0.05)$ according to the tissue. For each column, results with different superscripts letters $(\mathrm{x}, \mathrm{y}, \mathrm{z})$ differ $(\mathrm{P}<0.05)$ according to the diet.

Table 5. Fatty of total FA) of of pigs fed diets $(n=35)$

\begin{tabular}{|c|c|c|c|c|c|c|c|}
\hline & diet & $\mathrm{SCH}$ & $\mathrm{IH}$ & $\mathrm{SCN}$ & SCB & belly & flare fat \\
\hline & $\mathrm{C}$ & $23.13^{\mathrm{ax}}$ & $24.79^{\mathrm{a}}$ & $23.18^{\mathrm{ax}}$ & $24.20^{\mathrm{ax}}$ & $24.96^{\mathrm{a}}$ & $27.29^{\mathrm{b}}$ \\
\hline \multirow[t]{3}{*}{ C16:0 } & EL & $21.96^{\text {ay }}$ & $23.56^{\mathrm{a}}$ & $21.59^{\mathrm{ay}}$ & $22.98^{\text {ay }}$ & $26.12^{\mathrm{b}}$ & $26.47^{\mathrm{b}}$ \\
\hline & EL- & $21.50^{\text {ay }}$ & $23.50^{\mathrm{bc}}$ & $21.78^{\mathrm{ay}}$ & $22.81^{\text {aby }}$ & $23.80^{\mathrm{b}}$ & $26.13^{d}$ \\
\hline & $\mathrm{C}$ & $13.01^{\mathrm{a}}$ & $14.10^{\mathrm{ab}}$ & $13.01^{\mathrm{a}}$ & $15.96^{\mathrm{b}}$ & $14.76^{\mathrm{b}}$ & $19.83^{\mathrm{c}}$ \\
\hline \multirow[t]{3}{*}{ C18:0 } & EL & $13.23^{\mathrm{a}}$ & $13.90^{\mathrm{ab}}$ & $12.38^{\mathrm{a}}$ & $15.58^{\mathrm{b}}$ & $16.48^{\mathrm{b}}$ & $19.98^{\mathrm{c}}$ \\
\hline & EL- & $12.58^{\mathrm{a}}$ & $13.85^{\mathrm{ab}}$ & $12.14^{\mathrm{a}}$ & $15.38^{\mathrm{ab}}$ & $14.69^{b}$ & $20.18^{c}$ \\
\hline & $\mathrm{C}$ & $38.94^{x}$ & $36.22^{b x}$ & 39.37 & $38.70^{x}$ & 38.66 & $33.49^{\mathrm{cx}}$ \\
\hline \multirow[t]{3}{*}{ C18:1 } & EL & $37.58^{\text {aby }}$ & $33.78^{\text {by }}$ & $38.29^{\mathrm{b}}$ & $37.24^{\mathrm{abxy}}$ & $34.66^{\mathrm{a}}$ & $31.97^{\text {bxy }}$ \\
\hline & EL- & $38.07^{\mathrm{xy}}$ & $33.49^{\text {by }}$ & 37.81 & $36.99^{y}$ & 37.27 & $30.76^{\text {by }}$ \\
\hline & $\mathrm{C}$ & $13.87^{\mathrm{a}}$ & $13.82^{\mathrm{a}}$ & $13.85^{\mathrm{a}}$ & $11.94^{\mathrm{ab}}$ & $11.03^{b}$ & $11.14^{\mathrm{b}}$ \\
\hline \multirow{3}{*}{$C 18: 2 n-6$} & EL & $14.17^{\mathrm{a}}$ & $14.84^{\mathrm{a}}$ & $14.50^{\mathrm{a}}$ & $12.22^{\mathrm{b}}$ & $10.63^{\mathrm{b}}$ & $10.68^{c}$ \\
\hline & EL- & $14.27^{\mathrm{a}}$ & $14.96^{\mathrm{a}}$ & $14.50^{\mathrm{a}}$ & $12.39^{\mathrm{b}}$ & $11.34^{\mathrm{b}}$ & $11.72^{\mathrm{c}}$ \\
\hline & $\mathrm{C}$ & $1.04^{\mathrm{ax}}$ & $0.98^{\mathrm{ax}}$ & $0.98^{\mathrm{ax}}$ & $0.73^{\mathrm{bx}}$ & $0.75^{\mathrm{bx}}$ & $0.73^{b x}$ \\
\hline \multirow[t]{3}{*}{ C18:3 n-3 } & EL & $3.87^{\text {ay }}$ & $4.01^{\text {ay }}$ & $3.80^{\text {ay }}$ & $3.68^{\text {ay }}$ & $2.96^{\text {by }}$ & $3.48^{\text {aby }}$ \\
\hline & EL- & $4.19^{\mathrm{az}}$ & $4.32^{\mathrm{ay}}$ & $4.10^{\mathrm{ay}}$ & $4.03^{\mathrm{ay}}$ & $3.35^{\text {by }}$ & $4.06^{\mathrm{az}}$ \\
\hline & $\mathrm{C}$ & $0.35^{\mathrm{a}}$ & $0.00^{\mathrm{bx}}$ & $0.01^{\mathrm{bx}}$ & $0.00^{\mathrm{bx}}$ & $0.08^{\mathrm{b}}$ & $0.05^{\mathrm{b}}$ \\
\hline \multirow[t]{2}{*}{$C 20: 5$ n-3 } & EL & $0.18^{\mathrm{a}}$ & $0.11^{\text {aby }}$ & $0.06^{\text {aby }}$ & $0.05^{\text {by }}$ & $0.13^{\mathrm{ab}}$ & $0.07^{\mathrm{ab}}$ \\
\hline & EL- & $0.27^{\mathrm{a}}$ & $0.08^{\text {bxy }}$ & $0.11^{\text {by }}$ & $0.05^{\text {by }}$ & $0.11^{\mathrm{b}}$ & $0.06^{\mathrm{b}}$ \\
\hline \multirow{3}{*}{$C 22: 5$ n-3 } & $\mathrm{C}$ & $0.09^{\mathrm{abx}}$ & $0.09^{\mathrm{abx}}$ & $0.08^{\text {aby }}$ & $0.07^{\mathrm{bx}}$ & $0.10^{\mathrm{ax}}$ & $0.07^{\mathrm{ax}}$ \\
\hline & EL & $0.18^{\mathrm{y}}$ & $0.18^{\text {aby }}$ & $0.18^{\mathrm{y}}$ & $0.16^{\mathrm{y}}$ & $0.16^{\mathrm{y}}$ & $0.15^{\text {ay }}$ \\
\hline & EL- & $0.21^{\mathrm{z}}$ & $0.21^{\mathrm{z}}$ & $0.21^{\mathrm{y}}$ & $0.17^{\mathrm{y}}$ & $0.20^{\mathrm{z}}$ & $0.17^{\mathrm{y}}$ \\
\hline \multirow{3}{*}{$C 22: 6 n-3$} & $\mathrm{C}$ & $0.08^{\mathrm{ab}}$ & $0.06^{\mathrm{a}}$ & $0.06^{\mathrm{a}}$ & $0.11^{\mathrm{b}}$ & $0.07^{\mathrm{a}}$ & $0.07^{\mathrm{a}}$ \\
\hline & EL & $0.07^{\mathrm{ab}}$ & $0.07^{\mathrm{a}}$ & $0.06^{\mathrm{b}}$ & $0.10^{\mathrm{a}}$ & $0.09^{\mathrm{a}}$ & $0.06^{\mathrm{a}}$ \\
\hline & EL- & 0.08 & $0.08^{\mathrm{ab}}$ & 0.06 & 0.11 & 0.09 & $0.08^{\mathrm{ab}}$ \\
\hline \multirow{3}{*}{$n-3$} & $\mathrm{C}$ & $2.13^{\mathrm{ax}}$ & $1.55^{\mathrm{bcx}}$ & $1.74^{\mathrm{abx}}$ & $1.14^{\mathrm{cx}}$ & $1.34^{\mathrm{bcx}}$ & $1.07^{\mathrm{dx}}$ \\
\hline & EL & $5.08^{\mathrm{ay}}$ & $5.14^{\mathrm{ay}}$ & $4.98^{\mathrm{ay}}$ & $4.71^{\mathrm{ay}}$ & $3.94^{\text {by }}$ & $4.29^{\text {bcy }}$ \\
\hline & EL- & $5.61^{\mathrm{az}}$ & $5.53^{\mathrm{ay}}$ & $5.42^{\text {ay }}$ & $5.13^{\mathrm{ay}}$ & $4.38^{\text {by }}$ & $4.94^{\mathrm{abz}}$ \\
\hline \multirow{3}{*}{$n-6$} & $\mathrm{C}$ & $14.64^{\mathrm{a}}$ & $14.55^{\mathrm{a}}$ & $14.51^{\mathrm{a}}$ & $12.41^{\mathrm{ab}}$ & $11.79^{b}$ & $11.56^{\mathrm{b}}$ \\
\hline & EL & $14.70^{\mathrm{a}}$ & $15.46^{\mathrm{a}}$ & $15.05^{\mathrm{a}}$ & $12.56^{\mathrm{b}}$ & $11.13^{\mathrm{b}}$ & $10.95^{\mathrm{b}}$ \\
\hline & EL- & $14.92^{\mathrm{a}}$ & $15.58^{\mathrm{a}}$ & $15.03^{\mathrm{a}}$ & $12.77^{\mathrm{b}}$ & $11.87^{\mathrm{b}}$ & $12.03^{\mathrm{c}}$ \\
\hline \multirow{3}{*}{ SFA } & $\mathrm{C}$ & $37.84^{\mathrm{ax}}$ & $40.74^{\mathrm{b}}$ & $37.79^{\mathrm{ax}}$ & $41.74^{\text {bx }}$ & $41.57^{b}$ & $48.98^{c}$ \\
\hline & EL & $36.77^{\text {axy }}$ & $39.26^{\mathrm{ab}}$ & $35.52^{\text {ay }}$ & $40.12^{\mathrm{abxy}}$ & $44.36^{\mathrm{b}}$ & $48.25^{\mathrm{c}}$ \\
\hline & EL- & $35.57^{\text {ay }}$ & $39.07^{\mathrm{b}}$ & $35.48^{\text {ay }}$ & $39.70^{\text {by }}$ & $40.25^{\mathrm{b}}$ & $48.08^{c}$ \\
\hline \multirow{3}{*}{ MUFA } & $\mathrm{C}$ & $44.75^{\mathrm{ax}}$ & $42.44^{\text {ax }}$ & $45.33^{\mathrm{a}}$ & $44.08^{\mathrm{ax}}$ & $44.81^{\mathrm{ax}}$ & $37.97^{\mathrm{bx}}$ \\
\hline & EL & $42.78^{\text {aby }}$ & $39.34^{\text {bcy }}$ & $43.78^{\mathrm{a}}$ & $41.98^{\text {by }}$ & $39.92^{\text {bcy }}$ & $36.11^{\mathrm{cxy}}$ \\
\hline & EL- & $43.17^{\text {ay }}$ & $38.89^{\text {aby }}$ & $43.40^{\mathrm{a}}$ & $41.77^{\text {ay }}$ & $42.94^{\mathrm{axy}}$ & $34.52^{\text {bcy }}$ \\
\hline \multirow{3}{*}{ PUFA } & $\mathrm{C}$ & $17.41^{\mathrm{ax}}$ & $16.81^{\mathrm{abx}}$ & $16.88^{\mathrm{abx}}$ & $14.17^{\mathrm{bcx}}$ & $13.62^{\mathrm{cx}}$ & $13.05^{\mathrm{dx}}$ \\
\hline & EL & $20.44^{\text {ay }}$ & $21.40^{\mathrm{ay}}$ & $20.70^{\mathrm{ay}}$ & $17.90^{\text {by }}$ & $15.72^{\text {by }}$ & $15.64^{\operatorname{cxy}}$ \\
\hline & EL- & $21.25^{\text {ay }}$ & $22.03^{\text {ay }}$ & $21.11^{\text {aby }}$ & $18.53^{\text {bcy }}$ & $16.81^{\mathrm{cy}}$ & $17.40^{\mathrm{dy}}$ \\
\hline & $\mathrm{C}$ & $7.19^{\mathrm{ax}}$ & $9.44^{\mathrm{bcx}}$ & $8.68^{\mathrm{bx}}$ & $10.90^{\mathrm{cx}}$ & $8.86^{\mathrm{bx}}$ & $10.75^{b d x}$ \\
\hline \multirow[t]{2}{*}{$n-6 / n-3$} & EL & $2.90^{\text {ay }}$ & $3.02^{\mathrm{ay}}$ & $3.04^{\mathrm{ay}}$ & $2.66^{\text {by }}$ & $2.83^{\text {aby }}$ & $2.55^{\mathrm{cy}}$ \\
\hline & EL- & $2.66^{\mathrm{ay}}$ & $2.81^{\mathrm{ay}}$ & $2.77^{\mathrm{ay}}$ & $2.48^{\text {by }}$ & $2.70^{\text {ay }}$ & $2.42^{\text {by }}$ \\
\hline \multirow{3}{*}{ LA/ALA } & $\mathrm{C}$ & $13.42^{\mathrm{ax}}$ & $14.09^{\mathrm{abx}}$ & $14.26^{\mathrm{acx}}$ & $16.63^{b x}$ & $14.79^{\mathrm{cx}}$ & $15.19^{\mathrm{cx}}$ \\
\hline & EL & $3.68^{\text {ay }}$ & $3.71^{\text {ay }}$ & $3.83^{\text {ay }}$ & $3.33^{\text {by }}$ & $3.62^{\text {ay }}$ & $3.07^{\mathrm{cy}}$ \\
\hline & EL- & $3.41^{\text {ay }}$ & $3.45^{\mathrm{ay}}$ & $3.55^{\mathrm{ay}}$ & $3.07^{\text {by }}$ & $3.38^{\text {ay }}$ & $2.88^{\text {by }}$ \\
\hline \multirow{2}{*}{ UFA/SFA } & $\mathrm{C}$ & $1.65^{\mathrm{a}}$ & $1.46^{\mathrm{b}}$ & $1.66^{\mathrm{a}}$ & $1.40^{\mathrm{b}}$ & $1.41^{\mathrm{b}}$ & $1.04^{\mathrm{c}}$ \\
\hline & EL & $1.72^{\mathrm{ab}}$ & $1.55^{\mathrm{ac}}$ & $1.82^{\mathrm{b}}$ & $1.50^{\mathrm{c}}$ & $1.30^{\mathrm{d}}$ & $1.07^{\mathrm{e}}$ \\
\hline
\end{tabular}

acid content $(\%$ adipose tissue experimental 


$\begin{array}{llllll}\text { EL- } \quad 1.82^{\mathrm{a}} & 1.58^{\mathrm{b}} & 1.82^{\mathrm{a}} & 1.53^{\mathrm{b}} & 1.49^{\mathrm{b}} & 1.08^{\mathrm{c}}\end{array}$

$\mathrm{SCH}=$ subcutaneous adipose tissue of ham; IH, internal adipose tissue of ham; $\mathrm{SCN}=$ subcutaneous adipose tissue of neck; $\mathrm{SCB}=$ subcutaneous adipose tissue of back, $\mathrm{C}=$ control diet, $\mathrm{EL}=$ extruded linseed diet, $\mathrm{EL}-\mathrm{=}$ poor fiber extruded linseed diet, SFA = saturated fatty acids, MUFA = monounsaturated fatty acids, PUFA = polyunsaturated fatty acids, SFA = sum of SFA, MUFA = sum of MUFA, PUFA = sum of PUFA, n-6/n-3 = sum of n-6 fatty acids/sum of n-3 fatty acids ratio, LA/ALA = linoleic acid/linolenic acid ratio. For each line, results with different superscripts 
letters $(\mathrm{a}, \mathrm{b}, \mathrm{c})$ differ $(\mathrm{P}<0.05)$ according to the tissue. For each column, results with different superscripts letters $(\mathrm{x}, \mathrm{y}$, $\mathrm{z})$ differ $(\mathrm{P}<0.05)$ according to the diet.

Legend of the figure

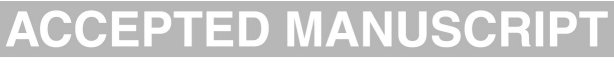

Fig 1. Relationship between lipid content and proportion of saturated fatty acids of adipose tissues ( $\square \mathrm{C}$ diet, $\triangleleft$ EL diet, $\boldsymbol{\Delta}$ EL- diet)

Fig 2. Relationship between proportion of monounsaturated and polyunsaturated fatty acids of adipose tissues ( $\square \mathrm{C}$ diet, $\triangleleft$ EL diet, $\boldsymbol{\Delta}$ EL- diet)

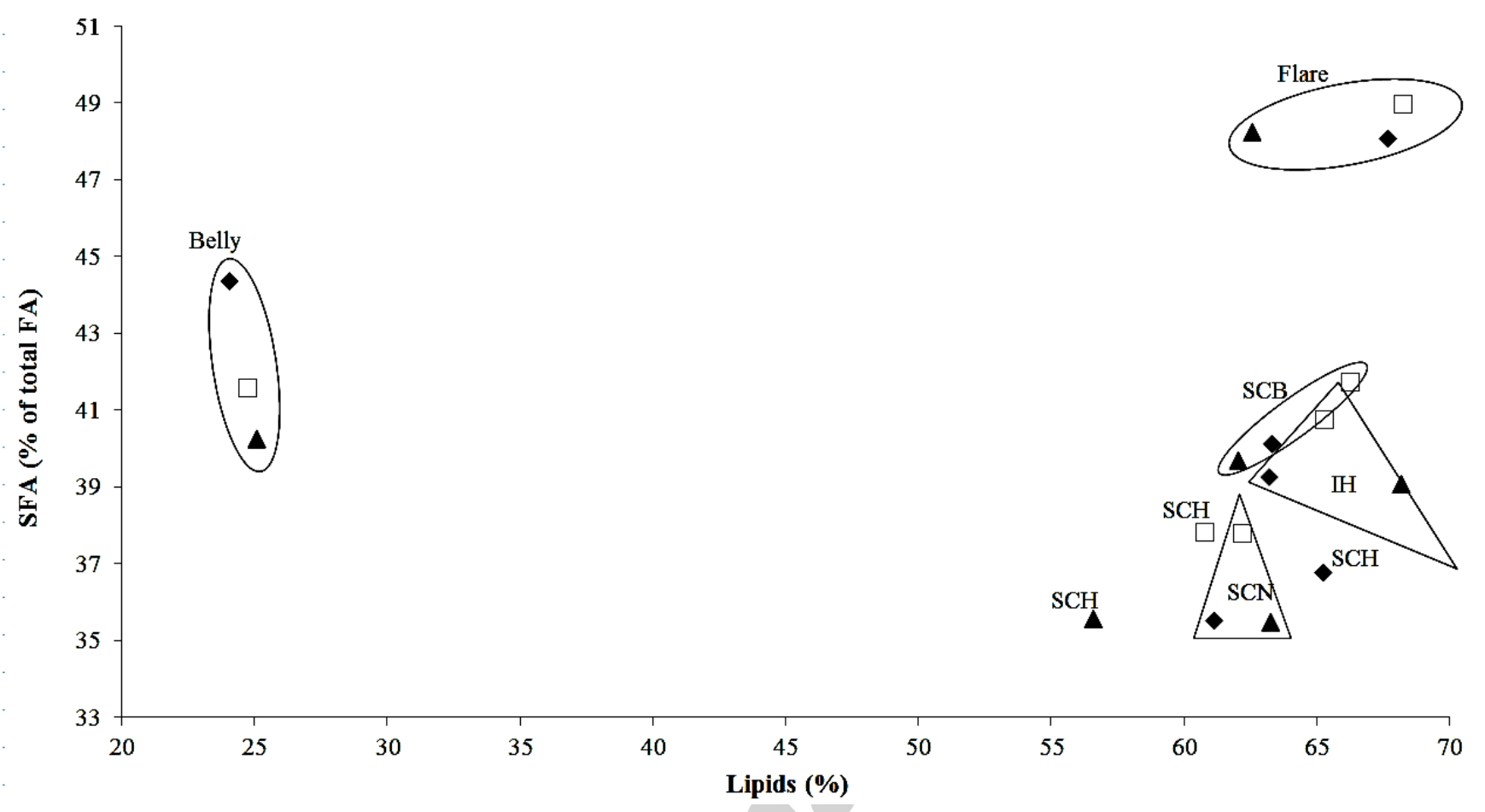




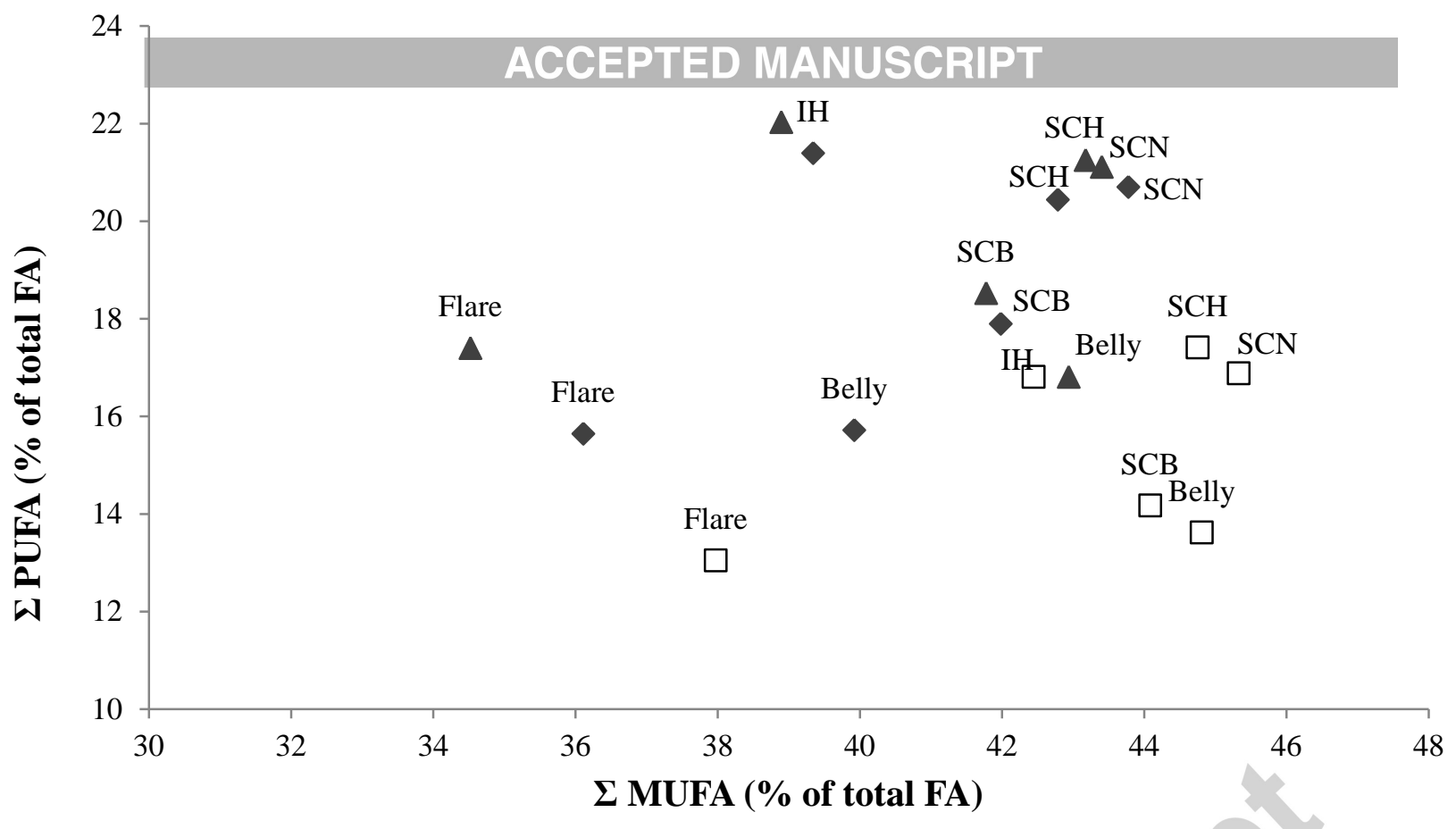

\section{Research highlights}

A supply of dehulled extruded linseed increased by 18, 19, 9 and $17 \%$ the C18:3 n-3 content of longissimus dorsi muscle, the diaphragm, subcutaneous tissues and the flare fat respectively, compared to a supply of extruded linseed.

The flare fat was the tissue the most saturated, whereas the subcutaneous adipose tissue of the neck and the ham $(\mathrm{SCH})$ were the most polyunsaturated tissues regardless of the diet that pigs received.

The subcutaneous adipose tissue of the back was the richest in $\mathrm{C} 22: 6 \mathrm{n}-3$, whereas the SCH was the richest in C20:5 n-3. 